\title{
The Colonisation History of the Scandinavian Fauna Presented through Subfossil Finds along One of Its Major Immigration Routes; Scania, Southern Sweden
}

\author{
E. Rosengren
}

The Historical Museum, Lund University, Sweden

Copyright (C) 2015 by authors, all rights reserved. Authors agree that this article remains permanently open access under the terms of the Creative Commons Attribution License 4.0 International License

\begin{abstract}
Most of the Swedish subfossil finds of terrestrial mammals have been recovered from Scania. The contributing factors may be that the locally more abundant Late Weichselian sediment basins have been exposed through the extensive practice of peat cutting during the $19^{\text {th }}$ century, and that the public awareness of the significance of the bones and antlers found, prior to the birth of the modern archaeological science, led to them being acquired to research collections. They came to form the basis for the discovery and reconstruction of the postglacial re-colonisation history of the terrestrial fauna. Here, some of these spectacular finds of faunal remains are presented. Today we know that Scania, through the recurrent establishment of a land bridge connecting it to the European mainland, represented one of the major immigration routes into Scandinavia. Already in the Late Glacial the inhabitants of the disintegrating mammoth steppe colonised the newly deglaciated land. It was, however, mainly between c. 12,400 and $9500 \mathrm{cal}$. years BP, in part due to the existence of a more long lasting land bridge and the continuing amelioration of the climate, that the postglacial fauna in Sweden was formed.
\end{abstract}

Keywords Subfossils, Scania, Sweden, History of Science, Research Collections, Re-colonisation, Postglacial, Faunal History

\section{Introduction}

A remarkable proportion of the scarce Late Glacial and Early postglacial subfossil finds of terrestrial mammals from Sweden have been recovered from the geographical region of Scania, southernmost Sweden (fig. 1). The contributing factors may be that the conditions for preservation are more favourable in this area and that the more common Late Weichselian sediment basins through the extensive practice of peat cutting for fuel have been exposed to a greater extent

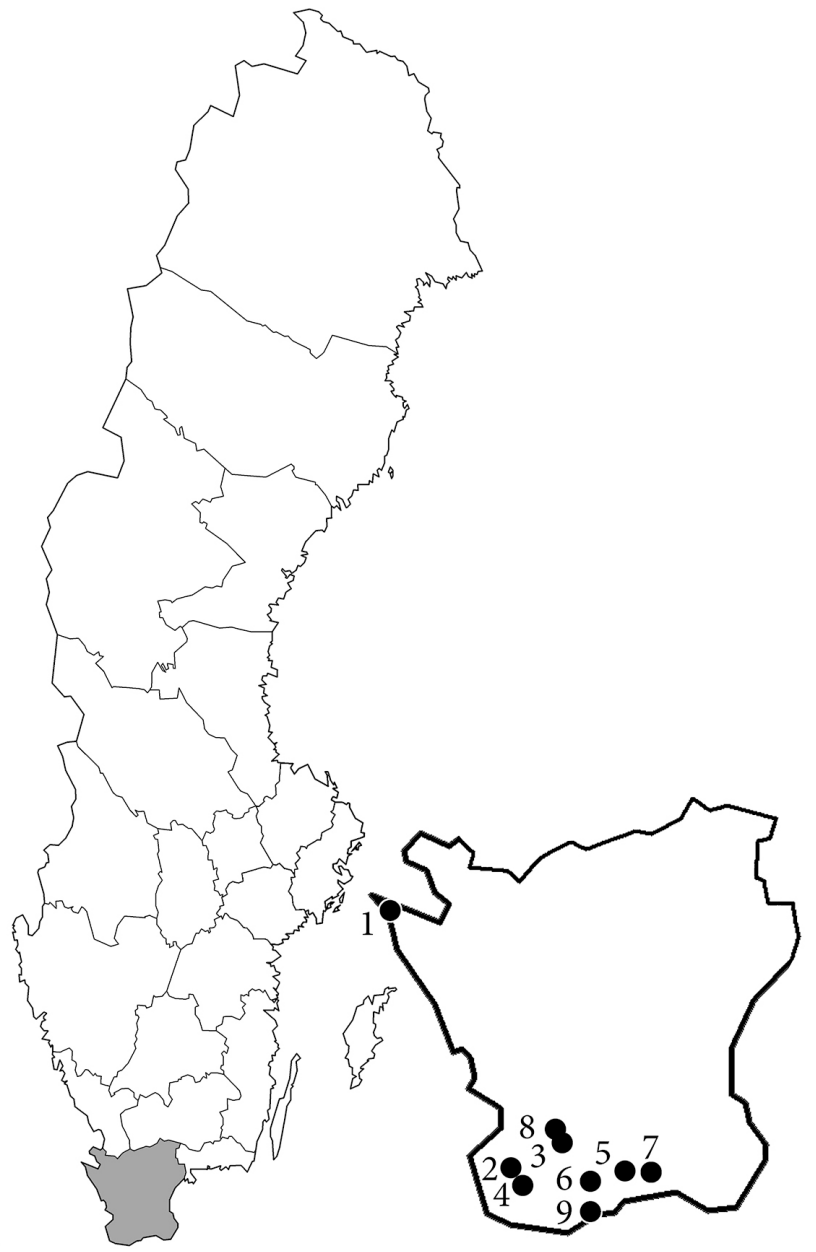

Figure 1. Scania; the southernmost region of Sweden with the sites of the finds marked. 1) Kullaberg, 2) Lockarp, 3) Hässleberga, 4) Östra Grevie, 5) Ugglarp, 6) Önnarp, 7) Bjäresjö mosse, 8) Brågarp, and 9) Skateholm.

here, than in many other areas of the country.

Also, through the workings of pioneers like the renowned Swedish zoologist Sven Nilsson (1787-1883) (fig. 2), and 
later by the Peat Bog Commission, the relatively high public awareness of the significance of the bones and antlers that was found have further led to the subfossils being acquired to research collections, like the ones at Lund University [1]. In fact, more than half of the so called "Peatbog finds" in the zoological collection of the Biological Museums in Lund were acquired prior to 1861 [2].

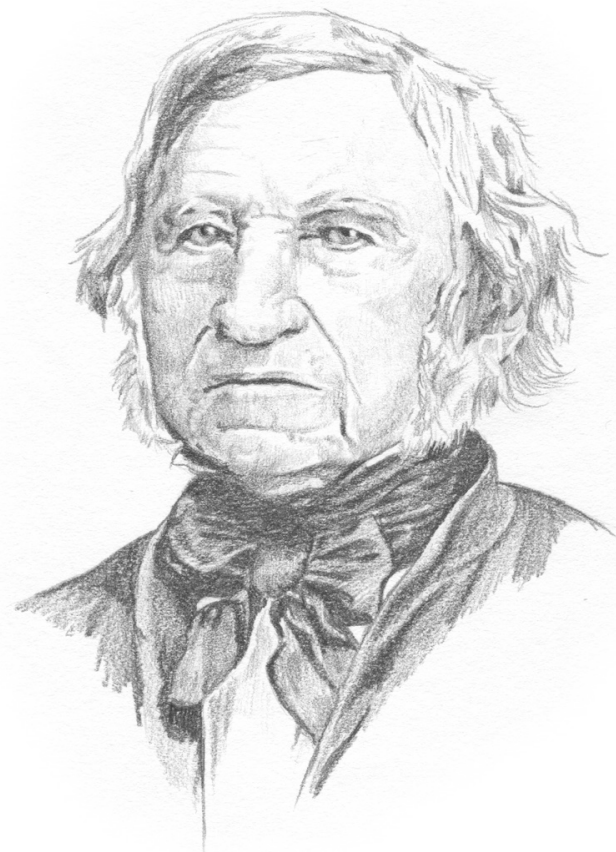

Figure 2. Professor Sven Nilsson (1787-1883). Illustration by the author.

These finds came to form the basis for Professor Sven Nilsson's discovery and subsequent reconstruction of the postglacial re-colonisation history of the terrestrial fauna in large parts of Scandinavia. Although a true pioneer in this work, he had somewhat of a weak spot for sensationalism. For instance, when a thigh bone from a polar bear (Ursus maritimus) was found at Kullaberg in the northwestern part of Scania in 1852, the theory of an Ice Age was not yet accepted and it was still inconceivable that polar bears had lived in Sweden. Therefore, it was initially interpreted by Sven Nilsson as a cave bear (U. spelaeus), the only one ever found in Sweden, on the basis of it being unusually large in comparison to the native brown bears [3, 4]. In an article from 1861 he argues for the similarities between the Scanian find and a replica of a cave bear femur he had received from France with great conviction $[5,6]$. The misclassification would remain for 50 years [7].

Continuous revisions have been made possible with the development of new techniques for extraction of scientific data like for instance radiocarbon dating. The aim of the following text is to recount for some of the historical finds of faunal remains that have had a particular significance for our understanding of the colonisation of the Scandianvian Peninsula. Many of which are related to the work of Professor Sven Nilsson. The specimen are accounted for chronologically. The dates cited have been obtained by calibrating the ${ }^{14} \mathrm{C}$ dates with IntCal09 ver. 4.2 (https://c14.arch.ox.ac.uk/). Dates are expressed as calendar years before the present $(=1950)$.

\section{Late Glacial. Following the Ice}

As the title of this paper reveal, Scania represented one of the major immigration routes into Scandinavia following the retreat of the inland ice. Continuous changes in sea level and land uplift led to a land bridge, connecting the south of Sweden to the European mainland, being established multiple times $[8,9]$. Three periods of particular importance can be identified. The Late Glacial finds of woolly mammoth in Scania derive from a relatively short time period when the land rose due to isostatic rebound while most of the water was still bound in the ice sheet.

\section{The Mammoth tusk from Lockarp}

A total of 33 finds, mostly tusks, of woolly mammoth (Mammuthus primigenius) are known from Sweden [10]. Though, only one, a fragment of a right-hand tusk, found in Lockarp a few kilometres south of Malmö in 1939, post-dates the Last Glacial Maximum (c. 25,000-20,000 cal. years BP) [11]. The fragment, about $135 \mathrm{~cm}$ long and weighing almost $8 \mathrm{~kg}$, probably comes from an adult female.

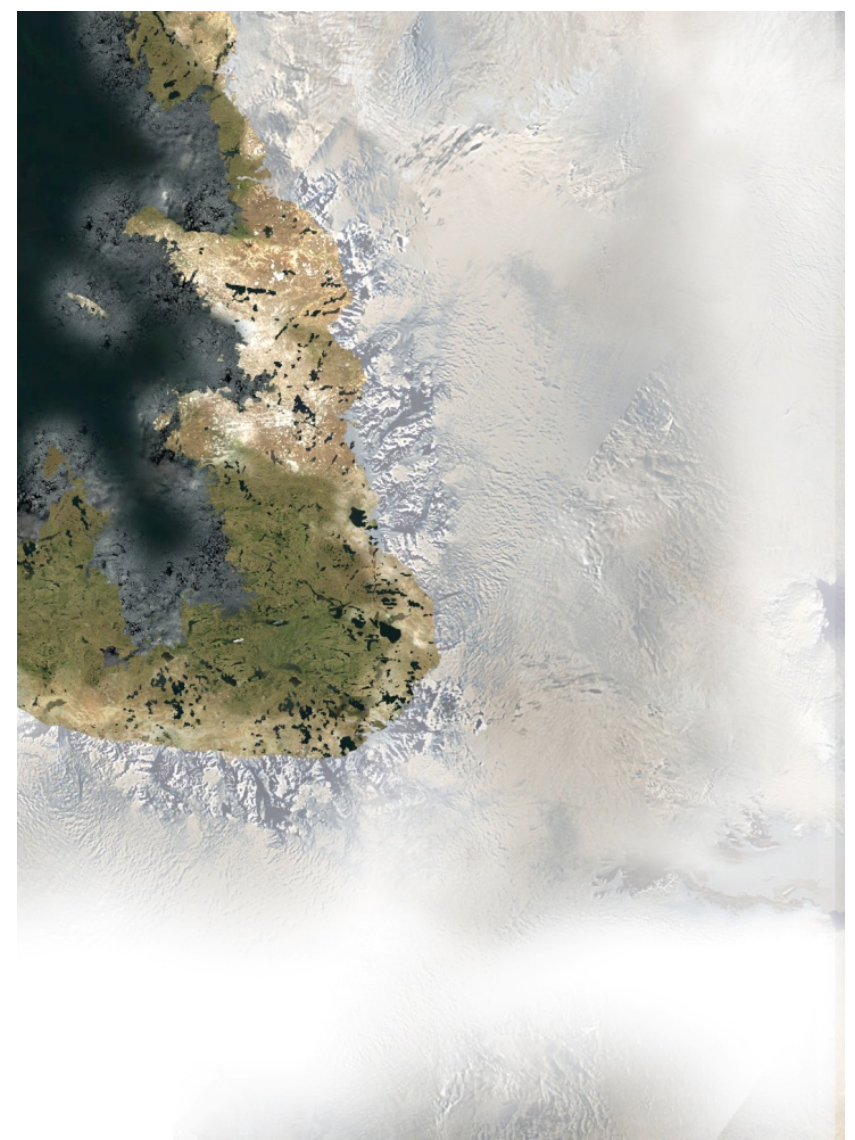

Figure 3. Reconstruction of the coastline and environmental conditions of Scania c. 16,000 cal. years BP. Illustration by the author. 
It shows little wear, ruling out that the tusk has been transported very far by either an ice sheet or ice river [12].

The Scandinavian Ice Sheet retreated from Scania about 17,000 years ago (fig. 3) and the Lockarp find has been radiocarbon-dated to c. 15,900 years ago [11], showing that the woolly mammoth was part of the periglacial fauna inhabiting Scania during a short time period while the ice sheet was melting. The tusk is part of the collections of the Department of Geology at Lund University.

\section{The reindeers of Hässleberga}

During the 1990s a total amount of $26 \mathrm{~kg}$ of skeletal remains was collected at Hässleberga, south western Scania. The material originated from a number of kettleholes that had been emptied and turned into cray fish ponds. The bones and antlers were then collected from the spread out sediments [13].

Some of the remains have been radiocarbon-dated to the warm period Allerød as well as the succeeding Younger Dryas period. When the depression across central Sweden became ice free, creating a provisional outlet to the Atlantic Ocean, the water level in the Baltic Sea Basin was rapidly reduced. As a consequence a land bridge to the continent was created between 13,000-12,600 years ago, making it possible for many of the cold-adapted species of land animals to immigrate to Scania $[8,9]$.

The recovered material from Hässleberga is the largest Late Glacial assemblage of reindeer (Rangifer tarandus) bones and antlers from a single site in Sweden. This, together with the first Late Glacial remains of wild horse (Equus ferus) and possibly arctic fox (Vulpes lagopus) makes the site the most important one for studies of the mammalian fauna in Sweden from this time period [13]. In addition, cut-marks made with stone tools as well as marrow fracturing on radiocarbon-dated reindeer bones indicate the presence of humans here at this time [14].

The remains are part of the zoological collection at the Biological museums at Lund University.

\section{The Irish Elk Antler from Östra Grevie}

Of the six finds of Irish elk (Megaloceros giganteus) that are known from Sweden, the youngest and most magnificent one is a shed right side antler found in 1938 during road construction in Östra Grevie, south of the city of Malmö [15, 16]. Measuring $1.6 \mathrm{~m}$ from the burr to the tip of the outermost tine and weighing almost $40 \mathrm{~kg}$, it probably once belonged to an adult individual in his prime.

When it was found, the shape of the antler was considered to resemble specimen from Ireland more than those from the continent [15]. The Irish breed was thought to be younger than the German breed, and this has later been confirmed by radiocarbon-dating [17]. The Östra Grevie antler has been dated to c. 12,800 cal.years BP, and the local extinction of the species at the onset of the Younger Dryas Stadial can most probably be explained by the decrease in annual temperature and overall vegetation productivity [18].

The antler is part of the zoological collection at the Biological museums at Lund University.

\section{The Postglacial. Re-colonisation in Earnest}

The most extensive land bridge existed between 12,400 and 9500 calendar years BP (fig. 4). This, in combination with the continuing amelioration of the climate that led to an ice free corridor through Finland being created, made it possible for the majority of the postglacial fauna to colonise Scandinavia from both the south and the northeast. This has had an impact on the genetic composition of a number of animal species, one notable example being the brown bear $[19,20]$.

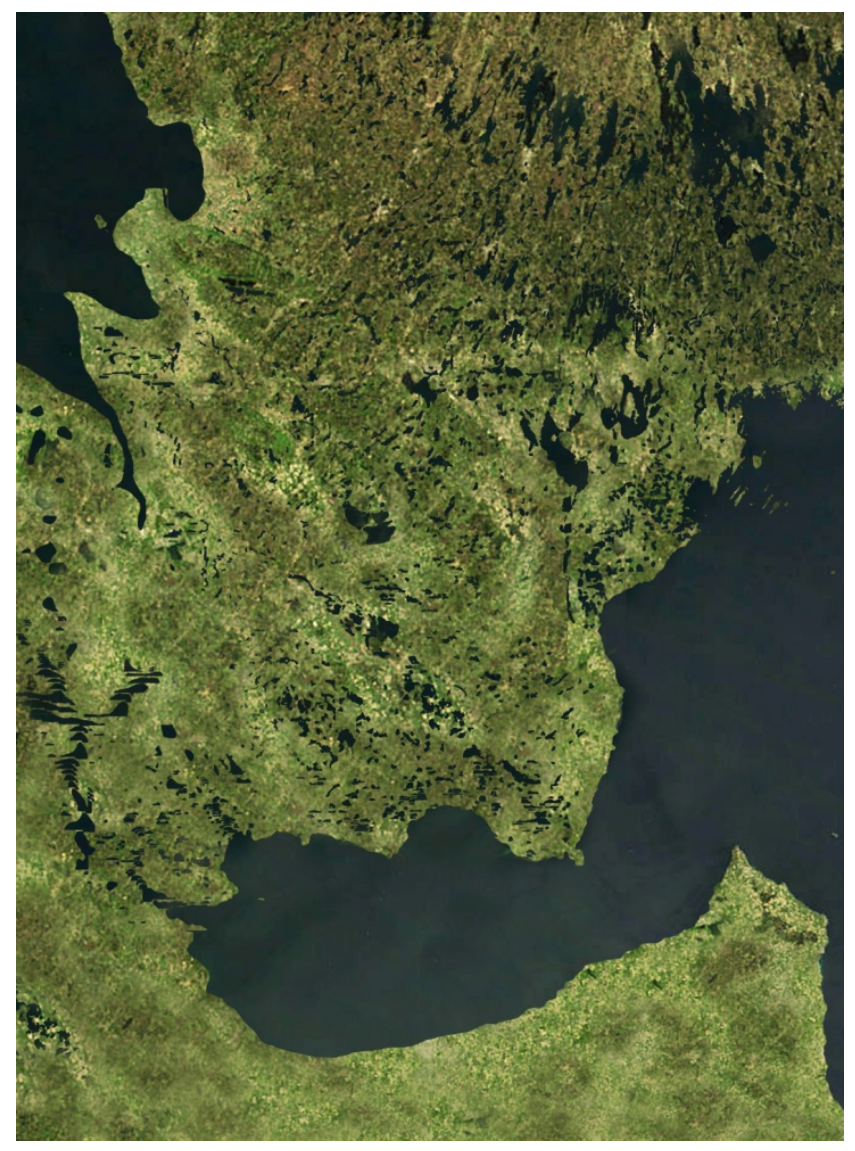

Figure 4. Reconstruction of the coastline and environmental conditions of Scania c. 11,000 cal. years BP. Illustration by the author.

\section{The brown bear from Ugglarp}

In 1893 an almost complete skeleton of a brown bear $(U$. arctos) was found at Ugglarp in southern Scania. Radiocarbon dated to c. 10,500 cal. years BP, it is the oldest brown bear skeleton found in Sweden [21]. The species is, 
however, believed to have inhabited Scania from about 13,000 years ago based on its occurrence in adjacent areas like Denmark [22].

The skeleton belonged to an old male displaying rheumatoid change in the right front paw and tooth loss. He also had a healed injury to the pelvis and a relatively fresh injury to one shoulder blade. Although he was large by comparison with present-day brown bears, he was a small individual compared with the contemporary bears from Denmark.

Tragically, bones disappeared when the specimen was exhibited at the museum of Geological Survey of Sweden in Stockholm. The canine teeth, as well as several of the small bones from the fore and back paws were stolen by visitors. More surprisingly, the penile bone was also stolen [21]. The Skeleton belongs to the Collections of the Geological Survey of Sweden

\section{The Aurochs from Önnarp}

The adamant bone collector professor Sven Nilsson describes the circumstances when the aurochs (Bos primigenius) skeleton from Önnarp was retrieved in his notes from the years 1840 to 1841 . He personally supervised the

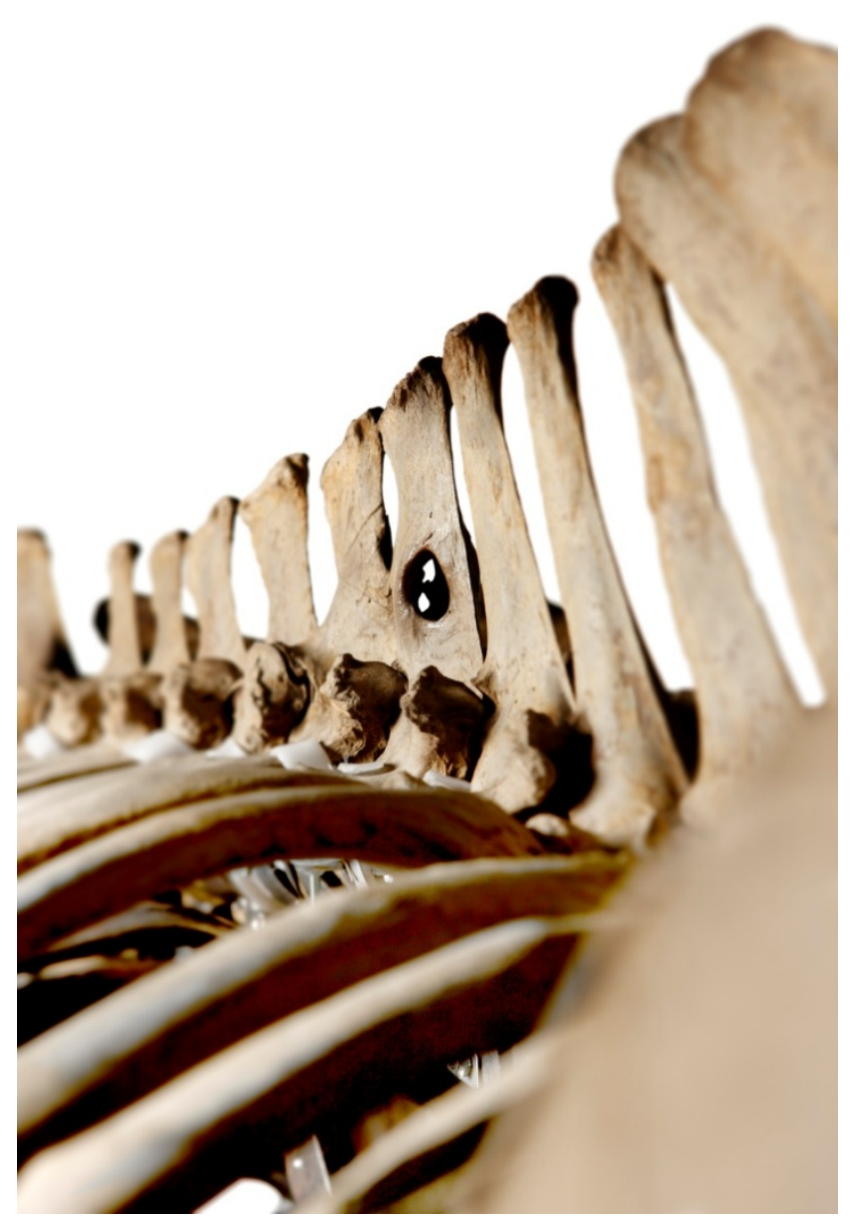

Figure 5. The partially healed injury to the vertebral column of the Önnarp Aurochs. Photo: Lucas Gölén. excavation and paid for the skeleton with his own money [1]. He thereby saved it from the bone mill and a fate as fertilizer. This was otherwise unfortunately a common fate for the bones found during peat cutting.

According to Nilsson, it was raining heavily during the excavation, and thus many small bones were washed away with the mud. These have been skillfully replaced by hand crafted wooden replicas in later times (Ronnie Liljegren, pers. com.). The tail was lent to the museum in Konigsberg [23] and allegedly lost when the city was bombed during the Second World War.

The skeleton, radiocarbon-dated to c. 10,300 cal. years BP $[23,24]$, is remarkable. The $6-8$ year old bull has been wounded in the back by an arrow from a Stone Age hunter and survived, at least long enough for it to partially heal [23] (fig. 5). This was observed already by Nilsson, who happily showed it to invited guests at night by candle light while he vividly told the story of the bull's injury (Påvel Nicklasson, pers. com.). His interpretation is as valid today as 147 years ago [25].

Aurochs lived in Scania as early as 11,500 years ago. Bones from specially selected parts are found on human settlement sites, showing that the species was mainly hunted for its meat. As the forest grew denser the aurochs became rarer, disappearing from Scania around 8600 years ago when human expansion and hunting forced it out of its former habitats [23]. The Skeleton is Part of the Zoological Collection at the Biological Museums at Lund University

\section{The bison from Bjersjöholm}

Ten confirmed finds of European bison (Bison bonasus) have been made in Sweden. Nine of them have been radiocarbon dated to within the second half of the Preboreal and Early Boreal period [26]. The most complete was found in a peat bog in Bjäresjö, southern Scania and donated to Lund University's zoological collection in 1812 by the then owner of the Manor of Bjersjöholm, Mrs Cock [25].

This bison, that died c. 10,800 years ago, had several ribs broken during its lifetime [23], presumably by goring. Sometime before 1949 the right hind leg was misplaced and has never been recovered [27]. In connection with the skeleton being sampled last year it was noticed that a missing scapula has been replaced with one from an aurochs (Rafal Kowalczyk, pers. com.). The skeleton belongs to the zoological collection at the Biological museums at Lund University.

Remarkably; the species disappeared from Scania already about 9600 years ago [26]. Human factors have been proposed as the main cause of the decline of European bison $[28,29]$, and this might hold true for large parts of western Europe during the mid- and late Holocene, but, oddly enough, there are no confirmed instances of bison hunting by humans in Scandinavia. Bone findings are most often associated with human settlements, and it is generally difficult to distinguish bison bones from those of aurochs in the highly fragmented material [23]. Consequently, it has only been possible to 
identify a large part of the archaeological material from southern Sweden as bovine.

\section{The Holocene Climatic Optimum}

\section{The European pond turtle shell from Brågarp}

The presence of this chelonian species in Scania can tell us a lot about the past environmental conditions. The pond turtle (Emys orbicularis) requires warm temperatures for an extended period of time for egg development and that is why the occurrence of the species in southern Sweden coincided with the Holocene Climatic Optimum about 10,100-5700 years ago [3, 30]. In Scandinavia turtles were collected sporadically by Stone Age people as food and raw material, and consequently their remains have been found at a few Scanian settlements, although most of the finds have been retrieved from bogs and other natural wetlands.

This shell of a European pond turtle (fig. 6), for example, was found during peat cutting in a bog at Brågarp, in south-western Scania in 1839 [31]. It is one of 38 Swedish finds, and for a long time it was the most complete and best preserved one [30]. There had been a few finds of pond turtle in Sweden prior to Professor Sven Nilsson acquiring this specimen but they had mostly been interpreted as the remains of kept turtles in ponds at medieval monasteries [32]. As a skilled geologist it became apparent to Nilsson that these remains were far older than that [33].

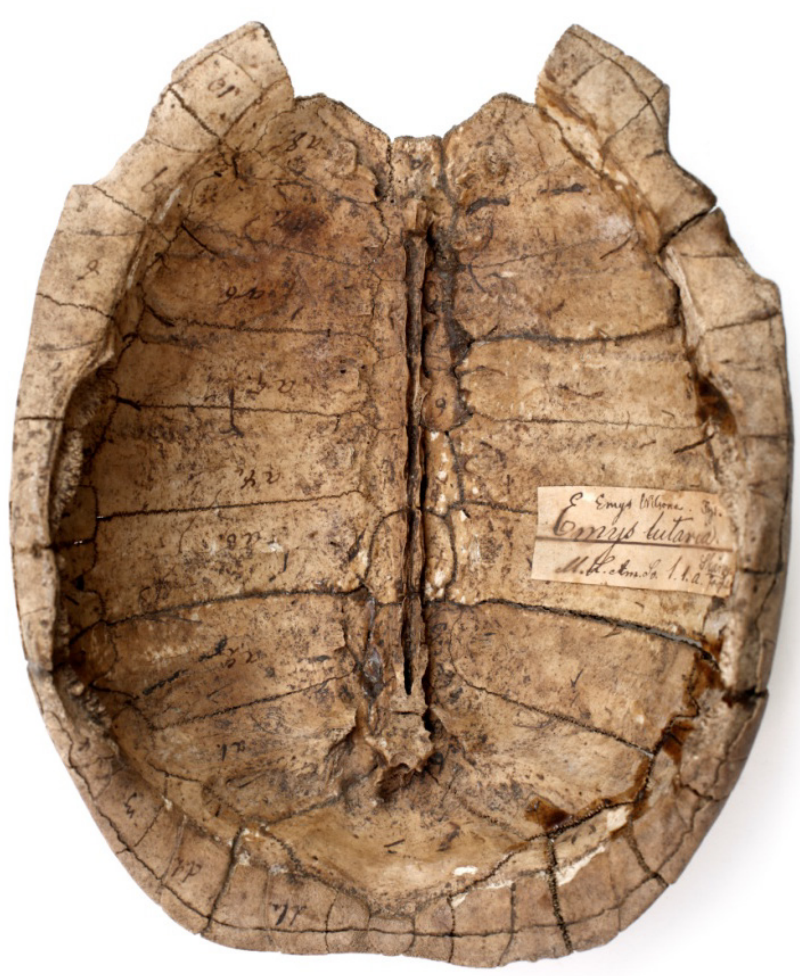

Figure 6. The shell of a European pond turtle from Brågarp. Photo: Lucas Gölén.
The youngest find from Scania is about 5500 years old and coincides with a period when the summer temperature fell rapidly. When it then grew warmer again, the water level in the oceans had risen, destroyed the land bridge to the continent and flooded the Baltic Sea Basin with saltwater. This effectively prevented the turtle from returning [30, 34].

The shell is part of the zoological collection at the Biological museums at Lund University.

\section{The Dalmatian pelican from Skateholm I}

One find of the middle part of an ulna from the Mesolithic settlement site Skateholm I, in southernmost Scania, has previously been proposed to belong to Dalmatian pelican (Pelecanus crispus) [35]. Since it is difficult to distinguish the bones of Dalmatian pelican from those of the white pelican ( $P$. onocrotalus), with which it share parts of its distribution area, and the fragment is so small it is uncertain whether it is possible to securely identify as to species on the basis of morphology alone [36]. The same is probably true for two proposed finds of Dalmatian pelican from Balltorp on the west coast of Sweden, made last year [37].

Finds have, however, recently been confirmed genetically in northern Germany [38], which together with the presumed remains of Dalmatian pelicans found in England, the Netherlands and Denmark [39, 40], implies that it had a much wider distribution c. 10,300-5000 years ago, making it likely that the species occurred also in Sweden.

The Skateholm find is housed at the Lund University Historical Museum.

\section{Conclusions}

The re-colonisation of Scania by terrestrial animals began as soon as the ice sheet had receded. The immigration was, however, delimited to periods when there existed a land bridge, connecting southern Sweden to the European mainland.

Before the dammed up meltwater from the inland ice in the Baltic Basin reached over the threshold of present day Öresund sound it was possible for land animals like the Woolly mammoth to cross over from Denmark into the western part of Scania. The next opportunity came $13,000-12,600$ years ago when the inland ice had receded past the depression across central Sweden creating a transient outlet to the Atlantic Ocean, thereby lowering the sea level in the Baltic Sea Basin, and draining the area of present day Denmark and Scania [4]. The land connection also coincided with a temporary amelioration of the climate, and this opportunity was seized by a number of cold-adapted species of land animals like the reindeer, wild horse, Irish elk, and probably brown bear.

The amelioration of the climate was interrupted, though, during the Younger Dryas leading to an advance of the ice sheet, which closed the outlet over central Sweden and once again dammed up the melt water. A narrow outlet to the 
Atlantic with large waterfalls ran through the Sound (Öresund). When the dam burst over central Sweden for the second time, the water level abruptly decreased $[8,9]$. In connection with this tapping a lasting land bridge was formed that enabled immigration of the majority of our postglacial fauna, for instance the Aurochs and the European bison.

The Holocene Climatic Optimum represented a possibility for more thermophilous species of animals like the European pond turtle and possibly Dalmatian pelican to inhabit Scania, at least for a short time period [4].

Finally, the story does not end here. With progress in for instance archaeogenetics, the subfossil finds continue to contribute to our knowledge, and will hopefully do so also in the future.

\section{Acknowledgements}

Special thanks go to Ph.D. Påvel Nicklasson who so generously shared his vast knowledge of the history of science in the 19th century and Sven Nilsson especially. For so generously having contributed with factual examination and counseling we wish to thank Professor Dan Hammarlund \& Professor Svante Björck, Department of Geology, Lund University.

\section{REFERENCES}

[1] Löwegren, Y. 1983. Sven Nilsson, zoologen. In Regnéll, G. (ed). Sven Nilsson. En lärd i 1800-talets Lund. Kungl. Fysiografiska Sällskapet i Lund. Lund. pp. 85-147

[2] Ekström, J., Furuby, E. \& Liljegren, R. 1989. Om tillförlitlighet och otillförlitlighet $\mathrm{i}$ äldre pollenanalytliska dateringar. In Iregren, E. \& Liljekvist, R. (eds.) Faunahistoriska studier tillägnade Johannes Lepiksaar. University of Lund, Institute of Archaeology Report Series 33, $13-20$

[3] Liljegren, R. och Lagerås, P. 1993. Från mammutstäpp till kohage, Djurens historia i Sverige. Wallin \& Dalholm. Lund.

[4] Rosengren, E. 2014. Sven Nilsson and the postglacial fauna of Scania. Lund university historical museum. Lund.

[5] Nilsson, S. 1860. Några rättelser och tillägg till "Skandinavisk Fauna". Öfvers. Vet. Akad. Förhandl. 1860. Stockholm.

[6] Nilsson, S. 1862. Funnos menniskor äfven i södra Sverige, redan den tid då elefanter, noshörningar och andra längesedan utdöda djurracer lefde i det sydligare Europa? Öfvers. Vet. Akad. Förhandling. 1861. Adertonde Årgången. Stockholm, pp. 41-51

[7] Berglund, B.E., Håkansson, S. \& Lepiksaar, J. 1992. Late Weichselian polar bear (Ursus maritimus Phipps) in southern Sweden. Sveriges Geologiska Undersökning, Ser. Ca 81, pp. $31-42$

[8] Björck, S. 1995. A review of the history of the Baltic Sea, 13.0-8.0 ka BP. Quaternary International, 27. S. 19-40
[9] Björck, S. 2008. The late Quaternary development of the Baltic Sea basin. In: The BACC Author Team (eds.). Assessment of climate change for the Baltic Sea Basin. Springer-Verlag Berlin Heidelberg. pp. 398-407

[10] Ukkonen, P., Arppne, L., Houmark-Nielsen, M., Kjær, K.H. \& Karhu, J.A. 2007. MIS 3 mammoth remains from Sweden implications for faunal history, palaeoclimate and glaciation chronology. Quaternary Science Reviews, 26:3081-3098

[11] Berglund, B.E., Håkansson, S. \& Lagerlund, E. 1976. Radiocarbon-dated mammoth (Mammuthus primigenius Blumenbach) finds in South Sweden. Boreas, vol. 5:177-191

[12] Persson, P.O. 1961. Skånska mammutfynd. Geol. Fören. Förhandl. BD. 83. H. 3. 1961.

[13] Magnell, O., Liljegren, R. \& Ekström, J. 1999. Hässleberga A Late Palaeolithic Kill Site in Scania, Sweden, Confirmed by Analysis of Bone Modifications. Lund Archaeological Review 5:5-19

[14] Larsson, L. 2012. Senpaleolitiskt hornhantverk från Hässleberga i Genarp, sydvästra Skåne (Late Paleolitic worked antler from Hässleberga, south-west Scania.) Fornvännen 107. Stockholm.

[15] Berlin, H. 1939. Jättehjorten från Östra Grevie. Skånes Hembygdsförenings årsbok 1939. Lund. S. 132-135

[16] Liljegren, R. 1975. Subfossila vertebratfynd från Skåne. University of Lund, Department of Quaternary Geology. Report 8.

[17] Stuart, A.J., Kosintsev. P.A., Higham, T.F.G. \& Lister, A.M. 2004. Pleistocene to Holocene extinction dynamics in giant deer and woolly mammoth. Nature, 431. S. 684-413

[18] Aaris-Sørensen, K. \& Liljegren, R. 2004. Late Pleistocene remains of giant deer (Megaloceros giganteus Blumenbach) in Scandinavia: chronology and environment. BOREAS Vol 33, Issue 1. 2004:61-73

[19] Taberlet, P., Swenson, J.E., Sandgren, F. \& Bjärvall, A. 1995. Localization of a contact zone between two highly divergent mitochondrial DNA lineages of the brown bear Ursus arctos in Scandinavia. Conservation Biology, 9(5):1255-1261

[20] Valdiosera, C.E., García, N., Anderung, C., Dalén, L., Crégut-Bonnoure, E., Kahlke, R.-D., Stiller, M., Brandström, M., Thomas, M.G., Arsuaga, J.L., Götherström, A. \& Barnes, I. 2007. Staying out in the cold: glacial refugia and mitochondrial DNA phylogeography in ancient European brown bears. Molecular Ecology, 16:5140-5148

[21] Iregren, E., Ringberg, B. \& Robertsson, A.-M. 1990. The brown bear (Ursus arctos L.) find from Ugglarp, southernmost Sweden. The skeleton, its age and environment. SGU. Avhandlingar och uppsatser, serie C, Nr. 824.

[22] Aaris-Sørensen, K. 2009. Diversity and dynamics of the mammalian fauna in Denmark throughout the last glacial-interglacial cycla, 115-0 kyr BP. Fossils and Strata. An international monograph series of palaeontology and stratigraphy. Nr. 57.

[23] Ekström, J. 1993. The Late Quaternary History of the Urus (Bos primigenius Bojanus 1827) in Sweden. Lundqua theses 29. Lund University, Department of Quaternary Geology. Lund.

[24] Aaris-Sørensen, K. 1999. The Holocene history of the 
Scandinavian Aurochs (Bos primigenius BOJANUS, 1827). In Weniger, G.-C. (ed.). Archäologie und Biologie der Auerochsen - Archaeology and Biology of the Aurochs. Wissenschaftliche Schriften des Neanderthal Museums, 1. Mettmann, pp. 49-57

[25] Nilsson, S. 1847. Skandinavisk Fauna. Däggdjuren. Andra upplagan. C. W. K. Gleerups Förlag. Lund.

[26] Liljegren, R. \& Ekström, J. 1996. The Terrestrial Late Glacial Fauna in South Sweden. In: Larsson, L. (ed.). The earliest settlement of Scandinavia and its relationship with neighbouring areas. Almqvist \& Wiksell International, Stockholm. pp. 135-139

[27] Isberg, O. 1949. Visenten (Bison bonasus arbustotundrarum Magn. Degerbøl) i Sverige jämte ett bidrag till dennes invandringshistoria. Lunds universitets årsskrift, N.F. Avd. 2. Bd 45. Nr 11. Lund:1-17

[28] Kerley, G.I.H., Kowalczyk, R., \& Cromsigt, J.P.G.M. 2012. Conservation implications of the refugee species concept and the European bison: king of the forest or refugee in a marginal habitat? Ecography 35:519-529

[29] Comsigt, J.P.G.M., Kerley, G.I.H. \& Kowalczyk, R. 2012. The difficulty of using species distribution modelling for the conservation of refugee species - the example of European bison. Diversity and Distributions 18:1253-1257

[30] Sommer, R.S., Fritz, U., Seppä, H., Ekström, J., Persson, A. \& Liljegren, R. 2011. When the pond turtle followed the reindeer: effects of the last extreme global warming event on the timing of faunal change in Northern Europe. Global Change Biology, 17:2049-2053

[31] Nilsson, S. 1841. Beskrifning öfver en i Skåne funnen fossil sköldpadda. Kongl. Vet. Acad. Handl. 1839. Stockholm.

[32] Söderbaum, H.G. 1932. Brevväxling mellan Berzelius och Sven Nilsson (1819-1847). Kungliga svenska vetenskapsakademien. Stockholm. (Letter from Sven Nilsson to Jacob Berzelius 15 Oct. 1839).

[33] Regnéll, G. 1983. Zoologen och arkeologen som var geolog. In Regnéll, G. (ed.). Sven Nilsson. En lärd i 1800-talets Lund. Kungl. Fysiografiska Sällskapet i Lund. Lund, pp. 23-83

[34] Sommer, R.S., Lindqvist, C., Persson, A., Bringsøe, H., Rhodin, A.G.J., Schneeweiss, N., Široký, P., Bachmann, L. \& Fritz, U. 2009. Unexpected early extinction of the European pond turtle (Emys orbicularis) in Sweden and climatic impact on its Holocene range. Molecular Ecology, 18:1252-1262

[35] Jonsson, L. 1988. The vertebrate faunal remains from the late atlantic settlement Skateholm in Scania, South Sweden. I: Larsson, Lars (red.). The Skateholm Project I - Man and Environment. ACTA. Lund.

[36] Ericson, P.G.P. \& Tyrberg, T. 2004. The early history of the Swedish avifauna. A review of the subfossil record and early written sources. Kungl. Vitterhets Historie och Antikvitets Akademiens Handlingar. Antikvariska serien, 45.

[37] Johansson, G. 2014. En 10000 år gammal boplats med organiskt material $i$ Mölndal. Ytterligare en överlagrad Sandarnaboplats vid Balltorp. Västra Götalands län, Västergötland, Mölndal stad, Balltorp 1:124, Mölndal 182. Uppdragsarkeologiska rapporter 2013-, Riksantikvarieämbetet

[38] Nikulina, E.A. \& Schmölcke, U. 2015. First archaeogenetic results verify the mid-Holocene occurence of Dalmatian pelican Pelecanus crispus far out of present range. Journal of Avian Biology 46:001-008

[39] Forbes, C.L., Joysey, K.A. \& West, R.G. 1958. On Post-Glacial Pelicans in Britain. Geological Magazine, 95(2), pp. 153-160

[40] Løppenthin, B. 1967. Danske ynglefugle i fortid og nutid. Odense Universitetsforlag. Odense. 